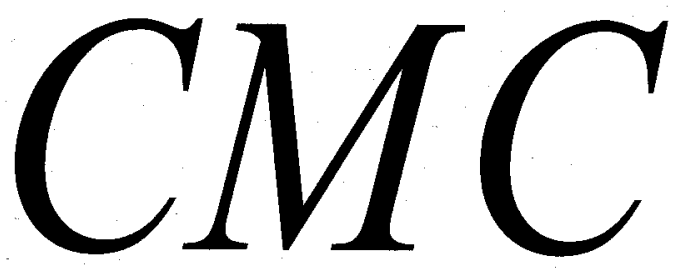

OCCASIONAL Papers

\title{
Cooperative Measures to Mitigate Asia-Pacific Maritime Conflicts
}

Commander Chai Wen-Chung

Taiwan Navy 
Issued by Sandia National Laboratories, operated for the United States Department of Energy by Sandia Corporation.

This report was prepared as an account of work sponsored by an agency of the United States Government. Neither the United States Government nor any agency thereof, nor any of their employees, nor any of their contractors, subcontractors, or their employees, makes any warranty, express or implied, or assumes any legal liability or responsibility for the accuracy, completeness, or usefulness of any information, apparatus, product, or process disclosed, or represents that its use would not infringe privately owned rights. Reference herein to any specific commercial product, process, or service by trade name, trademark, manufacturer, or otherwise, does not necessarily constitute or imply its endorsement, recommendation, or favoring by the United States Government, any agency thereof, or any of their contractors or subcontractors.

The views and opinions expressed herein do not necessarily state or reflect those of the United States Government, any agency thereof, or any of their contractors.

Printed in the United States of America. This report has been reproduced directly from the best available copy.

Available to DOE and DOE contractors from

U.S. Department of Energy

Office of Scientific and Technical Information

P.O. Box 62

Oak Ridge, TN 37831

Telephone:

(865) $576-8401$

Facsimile:

(865) $576-5728$

E-Mail: reports@Adonis.osti.gov

Online ordering: http://www.doe.gov/bridge

Available to the public from

U.S. Department of Commerce

National Technical Information Service

5285 Port Royal Rd.

Springfield, VA 22161

Telephone:

Facsimile:

E-Mail:

Online order:
(800) 553-6847

(703) 605-6900

orders@ ntis.fedworld.gov

http://www.ntis.gov/help/ordermethods.asp?loc=7-4\#online 


\title{
Cooperative Measures to Mitigate Asia-Pacific Maritime Conflicts
}

\author{
Commander Wen-Chung Chai \\ Taiwan Navy
}

Cooperative Monitoring Center Occasional Paper/29

\section{ii] Sandia National Laboratories}

Sandia is a multiprogram laboratory operated by Sandia Corporation, a Lockheed Martin Company, for the United States Department of Energy under contract DE-AC04-94AL85000. 
The Cooperative Monitoring Center (CMC) at Sandia National Laboratories assists political and technical experts from around the world to acquire the technology-based tools they need to assess, design, analyze, and implement nonproliferation, arms control, and other cooperative security measures. As part of its mission, the CMC sponsors research on cooperative security and the role of technology. Reports of that work are provided through the Occasional Papers series. Research is conducted by Sandia staff, international technical experts, and visiting scholars. (The CMC's Visiting Scholars Program is administered by the Institute for Public Policy at the University of New Mexico.) For additional information on the CMC's programs, visit the CMC home page on the World Wide Web at $<$ http://www.cmc.sandia.gov> or write to:

Cooperative Monitoring Center

Sandia National Laboratories

Mail Stop 1373

Albuquerque, NM 87185-1373

For specific information on this report contact:

John Olsen at the above address.

This report was prepared by Sandia National Laboratories

Albuquerque, NM 87185 and Livermore, CA 94550 


\section{Cooperative Measures to Mitigate Asia-Pacific Maritime Conflicts}

\section{Abstract}

The economies of East Asia are predominantly export based and, therefore, place special emphasis on the security of the sea lines of communication (SLOCs). Due to economic globalization, the United States shares these concerns. Cooperative measures by the concerned parties could reduce the potential for disruption by maritime conflicts. Primary threats against the SLOCs are disputes over the resources under the seas, disputes over some small island groups, disputes between particular parties (China-Taiwan and North-South Korea), or illegal activities like smuggling, piracy, or terrorism. This paper provides an overview on these threats, issue by issue, to identify common elements and needed cooperation. Cooperation on other topics such as search and rescue, fisheries protection, and oil spill response may help support improved relations to prevent maritime conflicts. Many technologies can help support maritime cooperation, including improved communications links, tracking and emergency beacon devices, and satellite imaging. Appropriate technical and political means are suggested for each threat to the SLOCs. 


\section{Acronyms}

$\begin{array}{ll}\text { AOE } & \text { area of responsibility } \\ \text { ARF } & \text { ASEAN Regional Forum } \\ \text { ASEAN } & \text { Association of Southeast Asian Nations } \\ \text { CBM } & \text { confidence building measure } \\ \text { CNOOC } & \text { China National Offshore Oil Company } \\ \text { CPC } & \text { Chinese Petroleum Company } \\ \text { DPRK } & \text { Democratic People's Republic of Korea } \\ \text { EEZ } & \text { Exclusive Economic Zone } \\ \text { EPIRB } & \text { Emergency Position-Indicating Radio Beacon } \\ \text { GPS } & \text { Global Positioning Satellite } \\ \text { IMB } & \text { International Maritime Bureau } \\ \text { IMO } & \text { International Maritime Organization } \\ \text { INCSEA } & \text { Incident at Sea Agreement } \\ \text { NIE } & \text { Newly Industrialized Economy } \\ \text { nm } & \text { nautical miles } \\ \text { NOWPAP } & \text { Northwest Pacific Action Plan } \\ \text { PLAN } & \text { People's Liberation Army Navy } \\ \text { PRC } & \text { People's Republic of China } \\ \text { ROK } & \text { Republic of Korea } \\ \text { SLOC } & \text { sea line of communication } \\ \text { UNCLOS } & \text { United Nations Convention on the Law of the Sea } \\ \text { UNEP } & \text { United Nations Environmental Program } \\ \text { VTS } & \text { Vessel Traffic Services }\end{array}$




\section{Contents}

1. INTRODUCTION................................................................................................................................ 11

2. POTENTIAL SOURCES OF DISRUPTION OF SLOCS ............................................................ 12

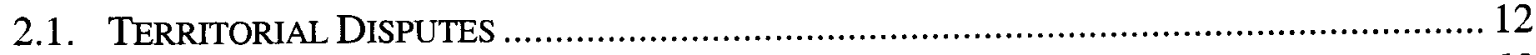

2.1.1. Northern Territories (Kuril Islands) ........................................................... 12

2.1.2. Diaoyutai/Senkaku Islands......................................................................... 13

2.1.3. South China Sea ....................................................................................... 15

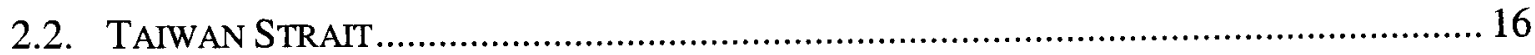

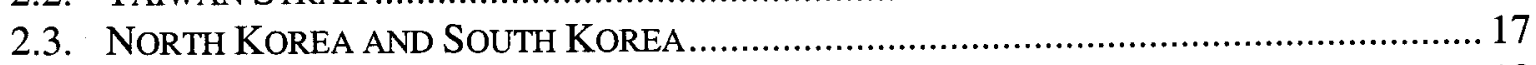

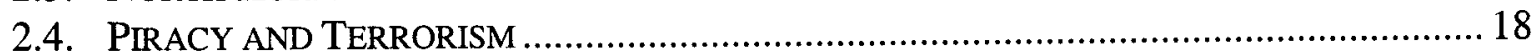

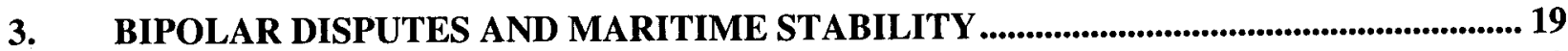

3.1. CHINA-TAIWAN RELATIONS AND THE TAIWAN STRAIT............................................... 19

3.1.1. Anti-smuggling ........................................................................................ 20

3.1.2. Oil Spill Control ..................................................................................... 20

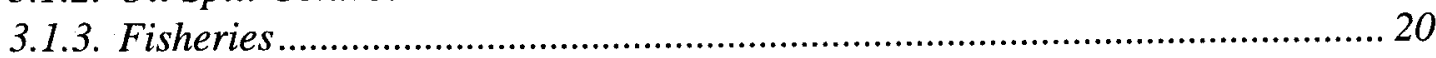

3.1.4. Maritime Resources Exploration and Exploitation........................................ 20

3.1.5. Illegal Immigration ................................................................................. 21

3.1.6. Direct Trade ……................................................................................... 21

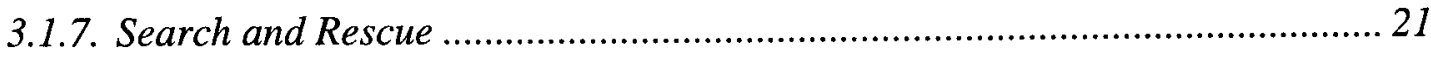

3.2. MARITIME ASPECTS OF NORTH-SOUTH KOREA DISPUTES ……………………......... 22

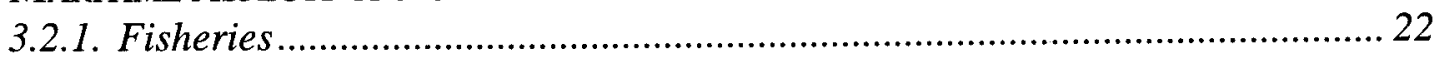

3.2.2. Shipping Routes.................................................................................... 22

3.2.3. Environmental Protection ............................................................................. 22

4. TECHNICAL MEANS TO SUPPORT RESOLUTION OF MARITIME ISSUES................. 23

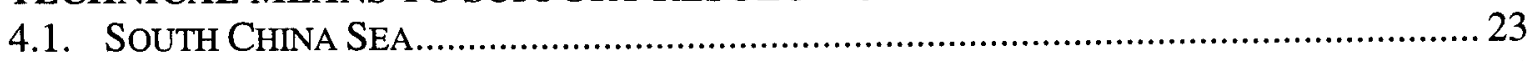

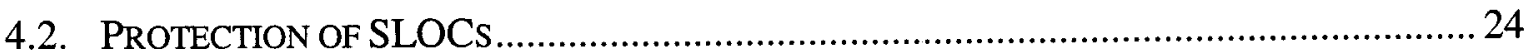

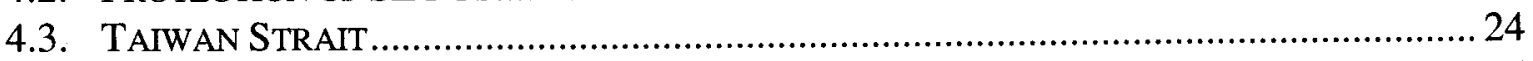

4.4. NORTH KOREA AND SOUTH KOREA ..................................................................... 25

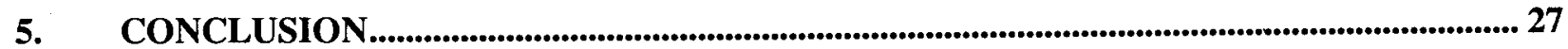

APPENDIX-PRINCIPAL TERRITORIAL DISPUTES OF EAST ASIA ......................................... 29

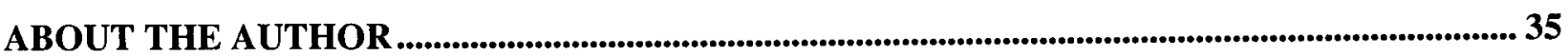

\section{Figures}

Figure 1. Areas affected by principal territorial disputes of East Asia. 
Cooperative Measures to Mitigate Asia-Pacific Maritime Conflicts

This page intentionally left blank. 


\section{Cooperative Measures to Mitigate Asia-Pacific Maritime Conflicts}

\section{Executive Summary}

An export-oriented economy is a common feature of Asia-Pacific nations. These nations export their products and merchandise around the world by sea and they also import raw material, energy (crude oil and natural gas), food, and other strategic materials by sea. Therefore, sea lines of communication (SLOCs) are a critical factor for the survival and prosperity of AsiaPacific nations. Cooperative measures by the regional parties may reduce the potential for maritime conflicts that might disrupt shipping. Maritime conflicts could arise from coastal states' attempts to control freedom of passage, domestic instability in coastal states, and contention among neighboring countries regarding overlapping maritime claims. Protecting the security of the SLOCs becomes a high security concern shared by many countries of the Asia Pacific.

Understanding the nature of potential maritime conflicts may help protect the SLOCs from disruption. Maritime territorial disputes over the Northern Territories (between Japan and Russia), the Diaoyutai/Senkaku Islands (China, Japan, and Taiwan) and the South China Sea (China, Taiwan, and some members of the Association of Southeast Asian Nations (ASEAN)), reflect issues of overlapping resource claims and unresolved colonial history. These disputed areas sit astride major trade routes. The South China Sea is especially important because most of the oil imported to Japan and South Korea passes through these waters. Confrontation between China and the ASEAN claimants could escalate to involve warships of the United States or Japan that would seek to secure safe passage for the tanker traffic. The other island disputes could irritate regional relationships, but are shown to be less threatening, simply because less is at stake.

Reunification is the core issue in relations between China and Taiwan and between North and South Korea. Because fundamental interests of the parties are at stake, tensions may be high. The Taiwan Strait or sea lines around the Korean peninsula could be disrupted by an outbreak of fighting over these core issues. Moreover, relatively minor maritime issues can be exacerbated by reunification tensions. In the Taiwan Strait, the maritime factors are smuggling, fisheries intrusions, oil spills, and illegal immigration. Between North and South Korea, maritime tensions exist over fisheries, shipping routes, and infiltration.

The final threats are beyond state control: piracy and terrorism. Piracy is particularly a problem in Southeast Asia because of corruption and domestic instability of certain coastal states. Terrorism, which may be indistinguishable from piracy, also grows in the absence of stable and effective governments.

Many forms of maritime cooperation could reduce tensions or the possibility of armed conflict. Some forms of cooperation could be useful in all of the areas: Search and rescue cooperation has a strong humanitarian aspect and can help improve maritime relations. Oil spill 
response also has promise, because no coastal country has adequate capability to deal with an accident involving a large tanker.

Other options are particularly suited to one area or another. Anti-smuggling cooperation could be most important for the Taiwan Strait, where confrontations have been triggered by such operations. Likewise, protection of fisheries is most important to the Koreas where shooting incidents have occurred between patrol boats escorting fishing vessels in disputed waters. Finally, anti-piracy coordination might be best for the South China Sea, where many incidents have occurred off the coast of Indonesia.

Other forms of potential cooperation include oceanic research, fisheries protection studies, and vessel traffic management in constricted waterways.

This paper points out several technologies that could support maritime cooperation. The technologies are mostly commercially available, but not commonly utilized in certain regions. Several types of cooperation would benefit from high-bandwidth communications between the respective authorities. This is particularly the case in anti-smuggling, anti-piracy, and search and rescue. Other measures such as vessel traffic control, fisheries protection, and search and rescue require wider use of tracking systems and automatic vessel identification devices. As a special case, tensions in the South China Sea might be reduced if all parties had better information about activities on disputed reefs and islets. Therefore, commercially available satellite imaging could be useful, especially if analyzed in a cooperative effort. 


\section{Cooperative Measures to Mitigate Asia-Pacific Maritime Conflicts}

\section{Introduction}

The Asia-Pacific is a maritime community with numerous islands and islets in the farflung waters of the region. The sovereignty of many islands is unresolved. During the Cold War era, Asia-Pacific nations tended to avoid conflicts regarding the islands and offshore resources in order to focus on their mutual opposition to the Soviet Union. That is, in the event of maritime conflicts, the scope and degree was limited by the self-restraint and bipolarity of the East-West international system. In the post-Cold War era, various national interests gained importance. Expanded national self-consciousness provoked more maritime conflicts in the Asia-Pacific region. In addition, the United Nations Convention on the Law of the Sea (UNCLOS), which entered into force in 1994, empowered countries to claim Exclusive Economic Zones (EEZs). Unfortunately, the claimed EEZs in East Asia overlap in many cases, merely intensifying regional maritime conflict. ${ }^{1}$ Moreover, the concept of the sea as national territory is a factor that drives Asia-Pacific nations to invest resources in naval force buildups in order to defend expanded national sovereignty and maritime interests. ${ }^{2}$

An export-oriented economy is another common feature of Asia-Pacific nations. These nations export their products and merchandise all around the world by sea and they also import raw material, energy (crude oil and natural gas), food, and other strategic materials by sea. Therefore, sea lines of communication (SLOCs) are a critical factor for the survival and prosperity of Asia-Pacific nations. The protection of SLOCs is a common value of Asia-Pacific nations. The security of SLOCs in the Asia-Pacific region faces many threats and challenges. Professor Michael Leifer summarizes the potential threats to shipping through international straits as (1) coastal states' attempts to control freedom of passage for national security; (2) domestic instability in coastal states; and (3) contention among neighboring countries regarding overlapping maritime claims. ${ }^{3}$ In fact, the same problems have appeared elsewhere in the AsiaPacific region. Therefore, strengthening and protecting the security of the SLOCs becomes a high security concern.

Promotion of naval transparency and monitoring of maritime activities can help resolve maritime conflicts and protect freedom of navigation among the Asia-Pacific nations. Coopera-

1 According to the UNCLOS, an EEZ may be established around islands only if these are capable of supporting human habitation. It can be argued that cays and sandbanks, some of which disappear at high tide and have no fresh water, cannot support a human community, but disputants would claim there is no bar to external support for nationals placed on what they claim to be sovereign territory. This paragraph quoted in Brian Cloughley, "No Need for War in South China Sea," International Defense Review, June 1995, p. 25.

Michael W. Everett and Mary A. Sommerville, eds., Multilateral Activities in Southeast Asia (Washington, D.C.: National Defense University Press, 1995), p. 21; Sam Bateman, "Economic Growth, Marine Resources and Naval Arms in East Asia: A Deadly Triangle?," Marine Policy, Vol. 22, No. 4, p. 297.

3 Michael Leifer, "The Security of Sea Lanes in Southeast Asia," Survival, Vol. 25, No. 1 (January/February 1983), p. 16. 
tive monitoring, the obtaining and sharing of agreed information among parties, ${ }^{4}$ may help achieve these two objectives. Cooperative monitoring emphasizes the use of sharable technologies to obtain data, equal access among all participating parties to the resulting data, and the provision for procedures for dealing with anomalies that may occur. Cooperative monitoring can strengthen transparency among parties, support confidence building measures (CBMs), and help maintain regional security.

This paper discusses the background of maritime conflicts in the Asia-Pacific region and the factors that influence SLOC security in order to find effective responses to resolve potential conflicts. The paper explores the threat posed by bipolar conflicts, specifically in the Taiwan Strait and between North and South Korea. Finally, the author applies the concept of cooperative monitoring to suggest measures to resolve maritime conflicts and protect the security of SLOCs. This paper promotes the concept of achieving regional stability through technical collaboration.

\section{Potential Sources of Disruption of SLOCs}

Nations have dissimilar security considerations, driven by differing circumstances and internal needs. For instance, Japan emphasizes energy, food, navigation, and shockproof safety, while nations that belong to the Association of Southeast Asian Nations (ASEAN) emphasize internal stability, national development, and social harmony as the core elements of national security. However, the economies of all Asia-Pacific countries place heavy dependence on seaborne exports and imports. Thus, the protection of merchant shipping is a task that no country in the region can ignore. ${ }^{5}$ Currently, maritime territorial disputes (the Northern Territories dispute between Japan and Russia; the Diaoyutai/Senkaku dispute among China, Japan, and Taiwan; and the South China Sea dispute among China, Taiwan, and some ASEAN nations), bipolar disputes (China-Taiwan and North-South Korea), and piracy and terrorism (particularly in Southeast Asia) threaten the safety of SLOCs. In the following, the author discusses the influence of these factors upon the safety of SLOCs. After first exploring the potential roots of disruption of SLOCs, the paper then identifies some effective measures for their protection.

\subsection{Territorial Disputes}

The following is a brief summary of the principal territorial disputes of East Asia. A more detailed discussion is available in the Appendix.

\subsubsection{Northern Territories (Kuril Islands)}

Japan has identified the Northern Territories as Etorofu, Kunashiri, Shikotan, and Habomai Islands, reaching northward to Kamchatka from the eastern end of Hokkaido (see

\footnotetext{
4 The author defines cooperative monitoring as the obtaining and sharing of agreed information among parties. For further information regarding cooperative monitoring, see Arian Pregenzer, "The Cooperative Monitoring Center: Achieving Cooperative Security Objectives Through Technical Collaborations," quoted in J. Marshall Beier and Steven Mataija, Verification, Compliance and Confidence Building: The Global and Regional Interface (Proceeding of the Thirteenth Annual Ottawa NACD Verification Symposium) (Toronto, Canada: Center for International and Security Studies, 1996), p. 89.

5 http://www-igcc.ucsd.edu/publications/policy_papers/pp3306.html.
} 
Figure 1). ${ }^{6}$ In August 1945, the Soviet Union declared war against Japan and then occupied the four islands. Since the end of World War II, the Kuril Islands dispute has been a stumbling block to Japan-Russia relations. ${ }^{7}$ Before the Soviet Union collapsed, Mikhail S. Gorbachev offered to return Habomai and Shikotan to Japan, because these two islands were of lesser military value to the Soviet Union. Japan insisted that all four islands of the Northern Territories must return to Japanese sovereignty and refused the offer. ${ }^{8}$

In October 1993, Russian President Boris Yeltsin visited Japan and he and then-Prime Minister Morihiro Hosokawa signed the Tokyo Declaration. They agreed that the guidelines for negotiations toward resolution would be (1) based on historical and legal facts, (2) based on documents compiled with the agreement of the two countries, and (3) based on the principles of law and justice. ${ }^{9}$ Currently, both sides are adhering to different strategies: Japan has asked Russia to recognize the Northern Territories as belonging to Japan and requires that Russia return the islands to Japan as soon as possible. On the other hand, Russia is focused on joint exploitation of the islands and links this issue to Siberian economic assistance by Japan.

For the Soviet Union, Japan, and the United States, the waters surrounding the Northern Territories are important strategic areas. Petropavlovsk is the most important naval base in the Soviet Pacific region. Located in the south of the Kamchatka Peninsula, its supply heavily depends upon Vladivostok. This supply line passes through Habomai Strait, northwest of Habomai Island. In addition, the Northern Territories are part of the definition of the Sea of Okhotsk apart from the Pacific Ocean. Therefore, the Northern Territories present Japan and Russia with a maritime sovereignty issue, but also involve important political, military, and economic issues. The sovereignty of the Northern Territories will probably not be successfully resolved in the short term.

\subsubsection{Diaoyutai/Senkaku Islands}

The Diaoyutai/Senkaku Islands are comprised of five islands and three rocks located about 120 nautical miles $(\mathrm{nm})$ northeast of Taiwan, $200 \mathrm{~nm}$ east of mainland China, and $190 \mathrm{~nm}$ southwest of Okinawa. ${ }^{10}$ The barren, uninhabited islands cover only about 6.3 square kilometers (see Figure 1). China, Taiwan, and Japan have adopted different approaches to dealing with the Diaoyutai/Senkaku Islands issue. For example, Japan's claim over the islands is based on the discovery that the islands were terra nullius (unclaimed). Taiwan declared that the Chinese discovered the "Diaoyutai Islands," but Taiwan did not follow international common practice and declare sovereignty over the islands by national pronouncement or official activities.

6 Captain James F. Giblin, Jr., "National Strategies and Japan's Northern Territories," Naval War College Review, Winter 1987, p. 53.

"Islands May Bridge Russia-Japan Gap," http://www.stratfor.com/home/giu/archive/03200.

"Strategic Considerations: Northern Territories Disputes Continued," United Daily, November 16, 1996, p. 10.

9

See http://www.mofa.go.jp/region/europe/russia/territory/overview.html.

The five islands are Huangwei Yu/Kuba-shima or Kobi Sho, Chiwei Yu/Taisho-jima or Akao-sho, Diaoyutai Dao/Uotshuri-shima, Beixiao Dao/Kita Kojima, and Nanxiao Dao/Minami Kojima or Minami-ko-shima. The three rocks are Dabeixiao Dao/Okino Kitaiwa, Dananxiao Dao/Okino Minamiiwa, and Feilai Dao/Tobise. See Rear Admiral William L. Schachte, Jr., "The United States' Role in the Diaoyutai/Senkaku Islands Dispute," quoted in International Law Conference on the Dispute over the Diaoyutai/Senkaku Islands between Taiwan and Japan (I-Lan: I-Lan County Government, 1997), p. 2. 


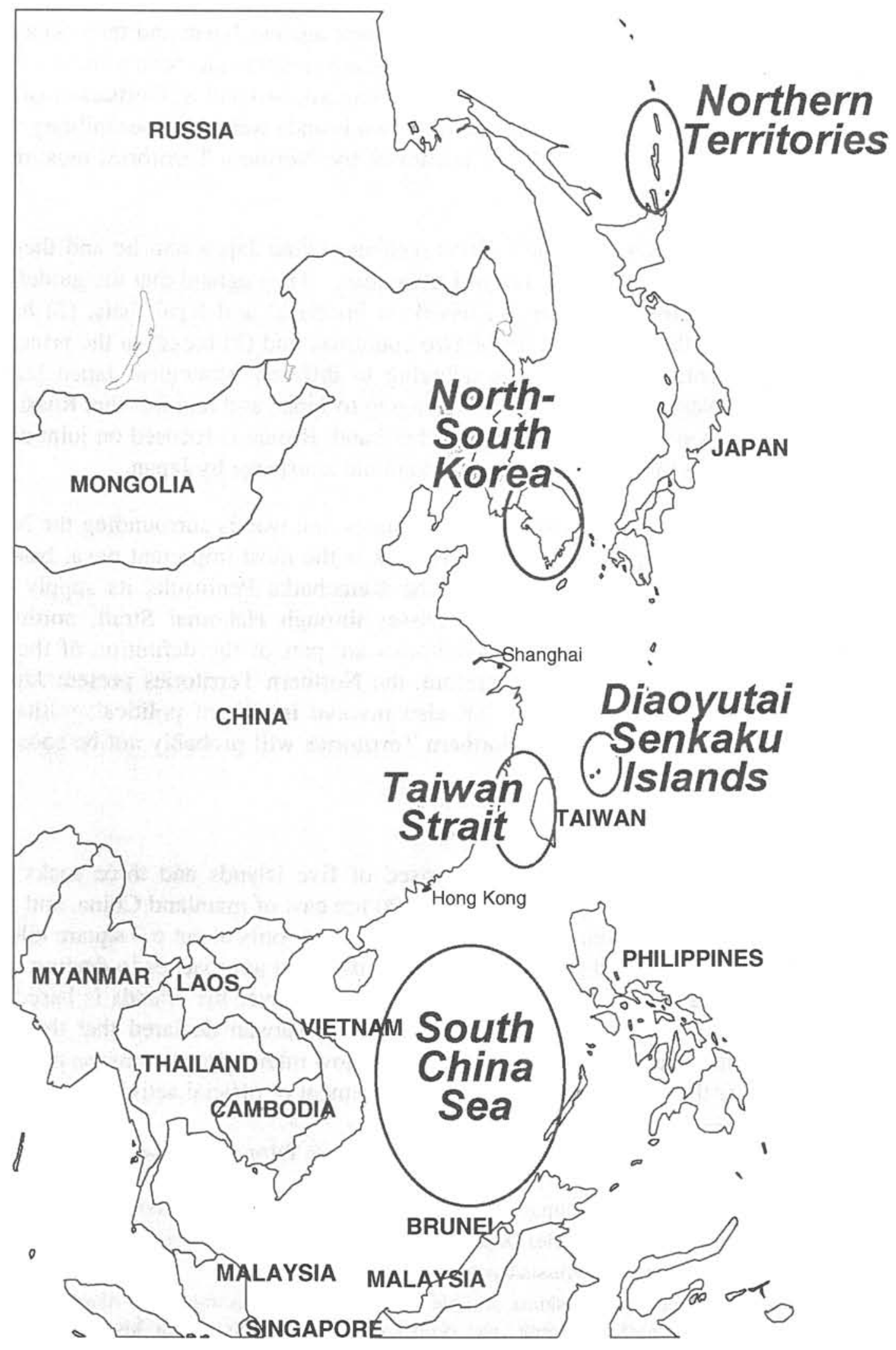

Figure 1. Areas Affected by Principal Territorial Disputes of East Asia 
In addition to Japan and Taiwan, China is also involved. Notably, China has not issued strong statements, using a restrained diplomatic approach to declaring sovereignty. Based on China's continued desire for Japanese economic assistance and investment, China has adopted a low-key approach toward the Diaoyutai Islands issue. ${ }^{11}$ Nevertheless, with the expansion of Chinese naval capabilities and the belief in the concept of the sea as national territory, China has attached increased significance to the islands. For example, Chinese intelligence ships have appeared in the nearby waters. Under these circumstances, China and Japan may clash over the sovereignty issue.

\subsubsection{South China Sea}

The South China Sea includes four disputed archipelagos: Paracel Islands, Pratas Islands, Macclesfield Bank, and Spratly Islands (see Figure 1). Of these, ownership of the Spratly Islands is the most contested. A 1995 study by Russia's Research Institute of Geology of Foreign Countries estimated that the equivalent of 6 billion barrels of oil might be located in the Spratly Islands area, of which 70 percent would be natural gas. Moreover, some Chinese specialists have asserted that the South China Sea could contain as much as 130 billion barrels of oil and natural gas. $^{12}$ It is perhaps inevitable that neighboring nations of the South China Sea would contest the rights to these enormous resources. Currently, the disputed areas are claimed all or in part by China, Taiwan, Vietnam, the Philippines, Malaysia, Brunei, and Indonesia. Conflicts have occurred between China and Vietnam, China and the Philippines, the Philippines and Malaysia, Vietnam and the Philippines, and the Philippines and China. ${ }^{13}$

The South China Sea and neighboring waters form the most important seaway in the world. Japan, Australia, and the nations of Southeast Asia send over 40 percent of their trade by sea through these waters, and the Newly Industrialized Economies (NIEs) of Hong Kong, Taiwan, and South Korea send more than one-quarter of their imports and exports through these SLOCs. In consequence, the economic vitality of these nations - and their trading counterparts clearly depends on these sea lines in the South China Sea. ${ }^{14}$ Therefore, the interruption of SLOCs in this region could have a major influence upon regional security and the global economy.

11 Chen Yeong-kang and Chai Wen-chung, "Modernization of the PLAN: Implications for Asian-Pacific Security," p. 11.

12 See United States Institute of Peace Special Report, "The South China Sea Dispute: Prospects for Preventive Diplomacy," http://www.usip.org/oc/sr/snyder/South_China_Sea1.html.

13 For a detailed description of related conflicts, see Lu Ru-chun et al., Hai Jun Shi (The History of People's Liberation Army Navy) (Beijing: PLA Press, 1989), p. 335; http://www.eia.doe.gov/emeu/cabs/schinatab.htm1\#TAB2; Trevor Hollingsbee, "China Moves In On Mischief Reef," Jane's Intelligence Review, January 1999, p. 5; Barbara Opall, "ASEAN Counters China Territorial Claims," Defense News, July 29 - August 4, 1996, pp. 4, 56; "Philippines Protests Attack By Vietnamese in Spratlys," Taiwan News, October 29, 1995, p. 5; "China Fishing Boat Collided with the Philippine Naval Ship on the Huangyan Dao in the South China Sea," United Daily, May 25, 1999, p. 13; "Philippine and Malaysia Fighting Aircraft Confrontation in the South China Sea Air," United Daily, November 3, 1999, p. 11; Run Bei, "What Does the Huangyan Dao Incident Represent?," Jian Chuan Zhi Shi (Warships and Merchant Ships) (Beijing), No. 214 (July 1997), p. 10.

14 John H. Noer and David Gregory, Chokepoints: Maritime Economic Concerns in Southeast Asia (Washington, D.C.: National Defense University Press, 1996), p. 4; "SLOCs in the Southeast Asia Are the Strategic and Economic Life Line," United Daily, March 20, 1997, p. 10. 
Sovereignty issues have led to armed clashes in the South China Sea area. In January 1974, China used military force against Vietnamese troops to enforce its claim to the Paracels. China clashed with Vietnam again at Johnson Reef in March 1988. In addition, naval confrontations have often occurred. In February 1995, China occupied Mischief Reef (claimed by the Philippines) and naval vessels of both sides moved into confrontation. ${ }^{15}$ In April 1997, China and the Philippines confronted each other for sovereignty of the Huangyan Dao. ${ }^{16}$ In May 1999, China used naval forces to engage in provocative action versus the Philippines, triggering continued tension between the two nations. ${ }^{17}$ If China used military force again to assert sovereignty and to advance its maritime interests, conflict would appear likely. In these circumstances, shipping in the region would assume high risks. Detouring to avoid the South China Sea would expend more fuel and time, increasing transportation costs.

\subsection{Taiwan Strait}

As with the South China Sea, tension in the Taiwan Strait may seriously impact the SLOCs. Because Taiwan is located at the juncture of Northeast Asia and Southeast Asia, most of Japan's imported energy arrives by sea lines adjacent to Taiwan (see Figure 1). ${ }^{18}$ For instance, Japan imports 700 million tons of raw materials and exports 70 million tons of manufactured products per year by sea. ${ }^{19}$ Forty percent of the imported material passes through the Malacca Strait, the South China Sea, and past Taiwan to Japan. ${ }^{20}$ In particular, 80 percent of Japan's imported crude oil passes through the same SLOCs northwards. In the event of conflict in the Taiwan Strait, Japanese economic survival and prosperity would be threatened. ${ }^{21}$

Taiwan poses a strategic consideration for Japan. In September 1997, the revised Guidelines for U.S.-Japan Defense Cooperation adopted a loose geographical definition that includes Taiwan in the scope of "the areas surrounding Japan." Later, Japan's chief cabinet secretary publicly stated that the guidelines were relevant for the Taiwan Strait area. ${ }^{22}$ The same view had been prefigured by other Japanese officials who declared that maintaining peace and stability in the Taiwan Strait is in Japan's vital interest. ${ }^{23}$ Some analysts claim that from the Japanese perspective, the revised guidelines were aimed primarily at Taiwan. ${ }^{24}$ In fact, in the early 1970 s,

15 James L. George, “China: Paper or Potential Tiger?," Naval Forces, February 1996, pp. 94-95.

16 Run Bei, "What Does the Huangyan Dao Incident Represent?," p. 10; Bei Fang, "The Truth of China and the Philippines Resolving the South China Sea Disputes," Guangjiaojing Monthly, December 1998, pp. 17-18.

17 Ian James Storey, "Manila Looks to USA for Help over Spratlys," Jane's Intelligence Review, August 1999, p. 50.

18 http://www.nwc.navy.mil/press/Review/2001/Autumn/art4-aul.htm

19 Huang Chao-moa translation, Japan Will be a Military Superpower (Taipei: The Bureau of History and Translation of Ministry of National Defense, 1995), p. 215.

20 John H. Noer and David Gregory, Chokepoints: Maritime Economic Concerns in Southeast Asia, pp. 24-25.

21 Rodney Tasker, "Ways and Means," Far Eastern Economic Review, May 11, 1995, p. 28.

22 Rex Li, "Partners or Rivals? Chinese Perceptions of Japan's Security Strategy in the Asia-Pacific Region," Journal of Strategic Studies, December 1999, p. 11.

23 Far Eastern Economic Review, October 9, 1997, p. 24.

24 Chris Rahman, "Defending Taiwan, and Why It Matters," Naval War College Review, Vol. LIV, No. 4 (Autumn 2001), available at http://www.nwc.navy.mil/press/Review/2001/Autumn/art4-aul.htm. 
Japan's famous defense analyst, Hideo Sekino, advocated that Japan should have capabilities for maintaining the safety of SLOCs between the homeland and Indonesia. ${ }^{25}$

If conflict occurs in the Taiwan Strait, Japan would be seriously impacted. South Korea could be drawn in also. Notably, Taiwan is located in a central position along the mainland China coastline, and three of four important Chinese trade SLOCs go through the Taiwan Strait. Thus, unblocked access to the Taiwan Strait is important for the national economy and international trade of mainland China. ${ }^{26}$ Therefore, all states that rely upon sea lines have strong interests in peace and stability in the Taiwan Strait. In other words, if armed conflict occurs in the Taiwan Strait, disruption of the SLOCs would affect the economies of all states in the region and many outside the region. ${ }^{27}$

\subsection{North Korea and South Korea}

The Korean Peninsula is another potential flashpoint in the Asia-Pacific region. For a long time, the isolation and alienation of the Democratic People's Republic of Korea (DPRK) has been extreme. If the unresolved Korean conflict developed into war, it would endanger the SLOCs neighboring the Korean Peninsula. Even though the importance of the SLOCs in this region are less than those of the South China Sea or the Taiwan Strait, impeded or disrupted SLOCs would seriously impact South Korea, Japan, China, and even the Russian Federation. These SLOCs are used to deliver crude oil to Japan's west coast, South Korea, and China's northern areas. Also, the most important seaways between China and Japan are located in this region.

Pronounced symptoms of the potential for conflict are the maritime incidents that have occurred between the two Koreas, and between the DPRK and Japan. In the past, North Korea has exchanged gunfire with South Korea (Republic of Korea, ROK) over fishing boats and with Japan over alleged spy/drug boats. There have also been ROK Coast Guard intercepts of DPRK coastal shipping vessels in declared defense zones of the ROK. The two sides lay conflicting claims to the surrounding waters and dispute the North-South maritime boundary. Although North Korean ships that violate the ROK-claimed border usually retreat when challenged by the South, ${ }^{28}$ jurisdiction disputes and protection of fisheries may trigger intense conflicts between the two Koreas.

In June 1999, a maritime incident involving North and South Korean ships sparked the first naval clash between the two Koreas since the Korean War. In this armed conflict, a North Korean torpedo boat was sunk and two other North Korean vessels were seriously damaged. About 30 North Korean sailors were believed killed. ${ }^{29}$ On July 29, 2002, two North Korean warships attacked one South Korean patrol vessel. The ensuing exchange left four South Korean

25 Peter J. Woolley and Mark S. Woolley, "The Kata of Japan's Naval Forces," pp. 63-64.

${ }^{26} \mathrm{Li}$ Ya-qiang, "The Geographic Values for Maritime Strategic of the Taiwan Islands," Jian Chuan Zhi Shi, January 1996, p. 16.

27 http://www.nwc.navy.mil/press/Review/2001/Autumn/art4-aul.htm.

$28 \mathrm{http}: / /$ asia.cnn.com/2002/WORLD/asiapcf/east/06/30/skorea.sailor.ap/index.html.

29 http://asia.cnn.com/2002/WORLD/asiapcf/east/07/01/korea.battle/index.html. 
sailors dead, one missing, and at least 19 injured. ${ }^{30}$ Due to the strong antagonism between the two Koreas, continued confrontations in the disputed waters could ignite tensions across the Korea Peninsula. If this situation deteriorates and develops into large-scale armed conflict, it would endanger the safety of SLOCs in the Yellow Sea and the Sea of Japan.

\subsection{Piracy and Terrorism}

Many piracy events have occurred in the Asia-Pacific region, particularly following the Asian financial crisis. Article 101 of the 1982 UNCLOS defines piracy as follows:

"Piracy consists of any of the following acts:

(a) any illegal acts of violence or detention, or any act of depredation, committed for private ends by the crew or the passengers of a private ship or a private aircraft, and directed:

(1) on the high seas, against another ship or aircraft, or against persons or property on board such ship or aircraft;

(2) against a ship, aircraft, persons or property in a place outside the jurisdiction of any State;

(b) any act of voluntary participation in the operation of a ship or of an aircraft with knowledge of facts making it a pirate ship or aircraft;

(c) any act inciting or of intentionally facilitating an act described in sub-paragraph (a) or (b)."

Today, acts of maritime piracy range from the classic boarding and hijacking of a merchant vessel on the high seas to the more common act of stealing from the ship while it is anchored. $^{31}$ In addition to the loss of crews and goods, piracy increases the operational and insurance costs. Environmental disasters could also be caused by piracy; if pirates attacked a fully loaded oil tanker, the result could be an oil spill that damaged marine life and other offshore resources and endangered the safety of maritime navigation. ${ }^{32}$

According to statistics compiled by the International Maritime Bureau (IMB), 262 cases of piracy occurred in the Asia-Pacific in the year 2000, about 56\% of the worldwide total of 469 . In 2001 , piracy cases in this region numbered 170 , about $51 \%$ of the worldwide total of $335^{33}$ However, the problem of piracy in global waters is far more serious than these figures suggest. According to the IMB, most shippers do not report pirate attacks against their vessels to avoid lengthy investigations, increased insurance premiums, and demands for extra crew pay. ${ }^{34}$

As indicated by past incidents, piracy has a transnational nature. Pirates take full advantage of the sensitivities over jurisdiction and sovereignty that continue to hamper concerted action against this crime. ${ }^{35}$ Therefore, the absence of law enforcement capabilities and resolution of sovereignty in the South China Sea exacerbates the piracy threat in Southeast Asia. It is

30 http://asia.cnn.com/2002/WORLD/asiapcf/east/06/30/korea.battle/index.html.

31 Dana R. Dillon, "Piracy in Asia: A Growing Barrier to Maritime Trade," The Heritage Foundation Backgrounder, No. 1379, June 22, 2000. See http://www.gasandoil.com/goc/reports/rex92790.htm.

33 International Chamber of Commerce (ICC), International Maritime Bureau, "Piracy and Armed Robbery Against Ships," Annual Report, January 1 - December 31, 2001 (U.K.: ICC International Maritime Bureau, 2002), p. 5.

34 Professor Peter Chalk, "Maritime Piracy: A Global Overview," Jane's Intelligence Review, August 2000, see http://www4.janes.com/search $97 \mathrm{cgi} / \mathrm{s} 97$ cgi?

35 "Southeast Asia Remains a Risk," Jane's Intelligence Review, April 1999, p. 5. 
unrealistic to expect piracy to diminish soon. Due to economic hard times, lack of government law enforcement, and corrupt local officials, piracy may continue to spread.

Terrorism is another serious threat to the safety of the SLOCs. Generally speaking, piracy involves crime for private gain, but terrorism is becoming an increasingly likely motive. To the victims, the results are indistinguishable. Incidents range from the capture of the cruise ship Achille Lauro by terrorists in 1985 to an attack by the Moro Islamic Liberation Front on a Filipino passenger ferry in $1997 . .^{36}$ Naval vessels may also be targets: the USS Cole was attacked by terrorists on October $12,2000 .^{37}$ As another variation, if a tanker were hijacked by terrorists, it could be used as a weapon to burn and sink in a harbor or in an SLOC, a terrible event for the safety of SLOCs and for maritime ecology.

For all of these reasons, protection of SLOCs in Southeast Asia must include strengthening the domestic stability of the ASEAN nations and resolving the South China Sea disputes. Cooperation on anti-piracy, anti-terrorism, and protection of SLOCs should integrate the efforts of governments, ship owners, and regional organizations to adopt appropriate measures to achieve these objectives.

\section{Bipolar Disputes and Maritime Stability}

In this section, we will discuss the bipolar issues of China-Taiwan and North-South Korea that may not directly affect the rest of the region. These problems receive less attention because international relations studies tend to focus on the strategic issues, rather than local problems. However, maritime issues have many interrelationships. A bipolar issue could trigger either a dangerous incident that could have disastrous consequences or could provide an opportunity to cooperate on common interests. If both sides can cooperate to resolve an issue, the process may improve relations and remove a potential flashpoint.

The following analysis suggests several opportunities for maritime cooperation between China and Taiwan. Currently, China and Taiwan have good relations in search and rescue and maritime resources exploration and exploitation. In addition to humanitarian reasons, other linkages could provide benefits, such as economic and environmental interests. For instance, oil spill control could provide for the collection of oceanographic data that could strengthen maritime scientific cooperation. Cooperating in nonmilitary areas could provide the groundwork for future opportunities to reduce military tension and promote stability across the Taiwan Strait.

\subsection{China-Taiwan Relations and the Taiwan Strait}

China and Taiwan are separated by the Taiwan Strait. Despite political antagonism, close civilian interactions, including cultural, social, and economic exchanges, still exist between China and Taiwan. The Taiwan Strait can either be the venue of a military confrontation that could develop into war or could provide opportunities for consultation to strengthen mutual trust and confidence. China and Taiwan are virtually island nations on trade issues. Therefore, both

\footnotetext{
36 David N. Griffiths, "Worldwide Piracy: Compiling the Facts," Maritime Affairs, Fall 1998, p. 16.

37 http://www.ict.org.il/articles/articledet.cfm?articleid $=138$.
} 
sides can discuss many maritime issues on the basis of common interests, including antismuggling, oil spill control, fisheries, maritime resources exploration and exploitation, illegal immigration, direct trade, and search and rescue.

\subsubsection{Anti-smuggling}

China and Taiwan have recognized the common threat posed by smuggling activities. The most common commodities smuggled from China to Taiwan are firearms, heroin, and illegal immigrants. For instance, in 1998 in Taiwan, seizures of smuggled heroin and amphetamines were about 70 kilograms and 600 kilograms, respectively, accounting for more than 50 percent and nearly 70 percent of the total seizures of that year. ${ }^{38}$ Thus, for Taiwan, smuggling is a serious social and internal safety problem. Conversely, smuggling has seriously reduced tax revenues for China. According to statistics from China, Fujian Province (which lies across the Strait from Taiwan) authorities cracked 99 smuggling cases worth US\$6.7 million in 1997. The corresponding lost customs duties cost China over US $\$ 2$ million. Therefore, China and Taiwan would both benefit from anti-smuggling cooperation.

\subsubsection{Oil Spill Control}

The distance between China and Taiwan is only around $100 \mathrm{~nm}$. If an oil spill occurred in the waters surrounding Taiwan, it might spread to China's Fujian and Zhejiang coastlines. Conversely, if an oil spill appeared on the southeast coastal region of China, it could damage the Taiwanese offshore fishing grounds. Therefore, both sides might choose to cooperate to prevent and control oil spills. The Northwest Pacific Action Plan (NOWPAP) of the United Nations Environmental Program (UNEP) has been developing a cooperative framework for a regional oil spill response involving China, Russia, Japan, and the Republic of Korea. This may provide a useful precedent for China and Taiwan.

\subsubsection{Fisheries}

Chinese fishing boats often attempt to trespass into Taiwanese fishing waters. There have been many disputes with Taiwanese fishing boats due to entangled nets, harassment, robbery, and collisions associated with trespassing ships. Moreover, some trespassing ships have engaged in the illegal use of electricity, poison, and dynamite for fishing. These trespassing boats have not only affected the Taiwanese fishermen's livelihood, but they have also depleted Taiwan's and China's fishing resources. ${ }^{39}$ Cooperating to combat illegal fishing activities could protect the safety of fishermen and preserve shared resources.

\subsubsection{Maritime Resources Exploration and Exploitation}

Since China and Taiwan lack plentiful land resources, exploration and exploitation of maritime resources are important paths for future prosperity. Therefore, both sides may wish to cooperate to explore and exploit maritime resources to further their respective economic interests. Through a multiyear effort, the China National Offshore Oil Company (CNOOC) of China and the Chinese Petroleum Company (CPC) of Taiwan have entered into a petroleum contract covering areas of the Taiwan Basin and Chaoshan Trough. CNOOC and CPC complement each

38 http://www.mac.gov.tw/english/MacPolicy/880322.html.

39

Ibid. 
other in this cooperation with their respective technology, management skills, and capital. Both parties expect to achieve mutual benefits. ${ }^{40}$ This pioneering example may provide a useful template for maritime resource cooperation.

\subsubsection{Illegal Immigration}

Due to asymmetry of economic development across the Taiwan Strait, many mainland Chinese use illegal means to enter Taiwan. In addition to economic reasons, some people enter Taiwan for intelligence gathering or illegal merchant activities. For Taiwan, stowaways from the Mainland have caused a serious internal problem and may also affect the security of Taiwan. According to statistics from the Bureau of Immigration of the Ministry of Interior, 42,342 stowaways were arrested from 1987 to May 2002.41 On the Mainland, China has arrested or detained many would-be illegal immigrants; for example, Fujian public security frontier guards detained 25 groups of illegal immigrants involving 3,265 persons in 1997. More effective coordination between Chinese and Taiwanese law enforcement organizations on this issue is another potential area of cooperation.

\subsubsection{Direct Trade}

For a long time, due to cross-Strait antagonism, both sides have had no direct postal, transportation, or commercial links. Current trade must route through transshipment ports, such as Hong Kong, increasing costs and decreasing economic incentives for cross-Strait industrial cooperation. As economic interactions have increased, China and Taiwan have recognized the important benefits of direct trade, by which both sides could sharply reduce transportation costs and personnel expenses. On January 1, 2001, Taiwan and China began the "Mini-Three Links" between Kinmen and Matsu of Taiwan and Xiamen and Fuzhou of China. As of June 30, 2002, 388 ships and 22,427 persons used the Mini-Three Links. The long-awaited expansion to include direct shipments between Kaohsiung in Taiwan and Fuzhou in China had barely begun as of this writing and had not yet become a regular route for traffic.

\subsubsection{Search and Rescue}

The Taiwan Strait is an important seaway between Northeast and Southeast Asia. Many maritime calamities have occurred in the Taiwan Strait during periods of bad weather. Thus, search and rescue is a potential area for maritime cooperation. In November 1997, the Taipeibased China Rescue Association and its mainland counterpart, the China Marine Rescue Center (Beijing) reached an agreement to set up a hot line to facilitate marine rescue work in the Taiwan Strait. Under the agreement, when accidents involving the ships of either Taiwan or China occur in the Taiwan Strait, the ships in distress and the rescuing ships may use the hot line to ask for help and request permission to enter the waters and harbors of the other side. ${ }^{42}$ Recently, China

40 http://english.pravda.ru/comp/2002/05/17/28896.html.

$41 \mathrm{http}: / /$ www.mac.gov.tw/statistic/ass_lp/appm2t2.htm.

42 "Hotline to Facilitate Rescue Work in Taiwan Strait," Central New Agency (FBIS-CHI-97-329), November 25, 1997, quoted in Kenneth W. Allen, "Confidence-Building Measures and the People's Liberation Army," The International Conference of the PRC Reforms at Twenty: Retrospect and Prospects (Taipei: National Chengchi University, 1999), p. 14. 
sent two salvage ships to help with rescue work for the China Airlines crash on May 25, $2002 .^{43}$ Taiwanese rescue helicopters also saved 133 Chinese fishermen from a burning boat off the southern port city of Kaohsiung on July 9, 2002. ${ }^{44}$ Search and rescue has already proved to be a fruitful area in China/Taiwan maritime cooperation.

\subsection{Maritime Aspects of North-South Korea Disputes}

Unlike China and Taiwan, no maritime cooperation exists between North Korea and South Korea. Moreover, there have been serious armed conflicts in the disputed waters. These developments not only damage North-South relations, but also endanger the safety of SLOCs in Northeast Asia. If the North and South engage in maritime cooperation that shows pragmatic benefits, provocative fishing and shipping activities may gradually decrease. Despite the tense situation, both sides still have an opportunity to engage in maritime cooperation in some fields, including fisheries, shipping routes, and environmental protection.

\subsubsection{Fisheries}

In the past several years, North Korea and South Korea have had many fishery disputes as noted above; armed patrols often escort fishing boats. If both sides fail to control fishing boat movements, an unintended naval confrontation could develop into widespread armed conflict. For example, the Falkland Islands War between the United Kingdom and Argentina originally derived from a fisheries dispute. In order to prevent fishing disputes from developing into armed conflicts, North and South Korea could cooperate to negotiate fishing rights, catch amounts, and fishing grounds. North Korea has reached such an agreement with Japan already.

\subsubsection{Shipping Routes}

The DPRK has declared a 200-nm EEZ and, within this EEZ, a 50-nm area designated as a "military zone." The DPRK restricts navigation within this military zone by prohibiting both overflight and navigation by foreign merchant ships and military vessels unless previous authorization has been granted. Similarly, South Korea also has established a "security zone" within the Sea of Japan (East Sea) adjacent to the border with North Korea, extending $150 \mathrm{~nm}$ from east to west and up to $75 \mathrm{~nm}$ from north to south. Shipping operations are prohibited within the zone. ${ }^{45}$ The two Koreas could discuss allowing innocent passage in conformance with the UNCLOS to avoid future incidents.

\subsubsection{Environmental Protection}

Initial maritime cooperation for the two Koreas might focus on responses to spills of oil or hazardous chemicals. Because maritime environmental protection would be a technical collaboration, not involving sovereignty and jurisdiction, it may have a high probability of acceptance. As a first, unilateral step, South Korea might provide a modest amount of cleanup

43 http://www1.chinadaily.com.cn/cndy/2002-05-27/71190.html

44 http://story.news.yahoo.com/news?tmpl=story\&u=/020709/168/1tkd0.html

45

Mark J. Valencia, "Northeast Asia: Transnational Navigational Issues and Possible Cooperative Responses," in Michael Stankiewicz, Maritime Shipping in Northeast Asia: Law of the Sea, Sea Lanes, and Security (California: IGCC of University of California, 1998), p. 26. 
capability for hazardous waste and oil in a harbor, such as Nampo, or at the mouths of the Yalu or Tumen Rivers. Thereafter, the two Koreas could expand maritime cooperation based on environmental protection.

In the long term, the two Koreas could cooperate to resolve potential maritime conflicts, including innocent passage, fishing rights, and disputed waters issues. Due to high political antagonism between North Korea and South Korea, more immediate cooperation might be based on maritime environmental protection, including oil spill control or chemical cleanup in harbors. Afterwards, both sides could discuss search and rescue, fishery agreements, and shipping routes. Finally, when both sides establish mutual trust and confidence, they could discuss sovereignty of disputed waters and negotiate an Incident at Sea Agreement (INCSEA) or naval code of conduct.

\section{Technical Means to Support Resolution of Maritime Issues}

This section discusses the use of technical means to support CBMs that can help defuse territorial disputes or help increase safety of the SLOCs. In the context of the bipolar disputes, technology can also support CBMs that could improve relations and help manage conflict either in the Taiwan Strait or between the two Koreas. Technical cooperation is a less politically charged approach that may not arouse strong opposition among participants. Moreover, it is a concrete and flexible approach to resolving maritime issues in the Asia-Pacific region.

\subsection{South China Sea}

Currently, territorial claimants have occupied islands and constructed landing strips, buildings, and facilities. This strategy is viewed as a method to establish a de facto presence, which they hope may become de jure ownership over time. ${ }^{46}$ To the extent that claimants agree to cease construction of new structures, a transparency regime may mitigate tension.

The emerging generation of commercial observation satellites offer imagery with many of the qualities necessary for supporting regional transparency CBMs. Higher resolution and more timely acquisition of imagery could support detailed analysis of structures and occupation of claimants. The new commercial satellites have higher resolution, greater timeliness, and a broad range of spectral capabilities that could help build confidence by enhancing transparency in the South China Sea through unobtrusive means. ${ }^{47}$ Ideally, images might be shared and analyzed by regional experts working together with shared technical tools (i.e., software) and skills (i.e., training workshops). With the assistance of commercial observation satellite images, claimants could verify cessation of new occupation and thereby mitigate tension and strengthen regional stability.

46 Scott Snyder, The South China Sea Dispute: Prospects for Preventive Diplomacy. A Special Report of the United States Institute for Peace (Washington, D.C.: USIP, 1996), p. 8, quoted in Vipin Gupta and Adam Bernstein, Keeping an Eye on the Islands: Remote Monitoring in the South China Sea, unpublished, p. 2.

47

John C. Baker and David G. Wiencek, "Sat-images Could be Spratlys' Salvation," Jane's Intelligence Review, February 1999, pp. 51-52, 54. 


\subsection{Protection of SLOCs}

Protection of SLOCs is a serious challenge for the Asia-Pacific countries. This issue involves many more factors than resolving maritime territory disputes. As previously noted, domestic instability, piracy incidents, and regional conflicts are influential factors that could affect the safety of SLOCs in this region. Because these factors are interrelated, we cannot resolve the SLOC issue by any single method or simple approach.

Tracking a vessel's position or status is an anti-piracy/anti-terrorism method on the high seas. The SHIPLoc device uses satellite communications to send periodic location and identification to a central monitoring system. Through this system, the vessel owner can access the data via a password-controlled Internet page. If the owner detects diversion of the vessel, he may contact the IMB's piracy center in Kuala Lumpur to activate regional police forces. Similar commercial tracking systems exist worldwide to fight piracy, hijacking, terrorism, and fraudulent operations.

Regional countries can use other modern technologies to strengthen the safety of the SLOCs. For instance, the Internet and other forms of telecommunication can support the collection, analysis, and sharing of information among nations for intelligence and cooperative monitoring purposes. Direct communication and coordination between shipowners, states, and International Maritime Organization (IMO) bodies are concrete measures for protection of SLOCs. Establishing nongovernmental Technical Working Groups (which could include shipowners from Taiwan) to study SLOC security could be critical for the Asia-Pacific.

\subsection{Taiwan Strait}

Taiwan and China share the Taiwan Strait for shipping, fishing, and undersea resources and the two sides are committed to cooperation in trade. Reflecting their common interests and problems, both sides could expand the scope of maritime cooperation. including:

Technical means are available to enhance maritime cooperation across the Taiwan Strait,

- Anti-smuggling and prevention of illegal immigration: Law enforcement personnel on both sides need to verify bills of lading of each other's vessels. Electronic customs forms, transmitted over the Internet, could expedite the processing of relevant information and thwart the use of altered and fraudulent documentation. Along with the credentials of the shipmaster, this information might help enforcement officials spot false declarations. For anti-smuggling purposes, both sides can establish a hot line and video conference link between their respective enforcement agencies. In addition, establishing coordinated patrols and shared training workshops could facilitate anti-smuggling activities on both sides.

- Oil spills: China may wish to include Taiwan in the NOWPAP "Regional Oil Spill Contingency Plan." During negotiations, China expressed the desire to name "parties" or "authorities," rather than "states." This may be an attempt to save a place at the table for Taiwan, or at least Taiwanese shipowners, and a good opportunity for both sides to engage in 
oil spill control and response through regional cooperation. Hot lines between response centers and oceanographic data exchanges are important components to containing and cleaning up oil spills in the waters adjacent to China and Taiwan.

- Maritime scientific cooperation: Potential topics for cross-Strait maritime scientific cooperation include migratory animal protection, pollution monitoring, resource (particularly oil and natural gas) exploration and exploitation, meteorological data sharing, and archaeology for sunken ships. Maritime authorities on both sides can select topics for cooperation, then devise work to be done at an academic or scientific level. Environmental remote sensing, computer simulation and modeling, data collection buoys, and hydrographic studies are all potentially suitable for maritime scientific cooperation.

- Search and rescue: As with oil spill control, search and rescue needs rapid response and highly coordinated operation. Therefore, Taiwan and China could establish hotline and videoconference capabilities that could facilitate communication in executing search and rescue operations. Both sides could assume areas of responsibility (AOEs) in the Strait and establish clear procedures for search and rescue. Installation of Emergency Position-Indicating Radio Beacons (EPIRBs) on all fishing vessels for communication with international maritime satellites would be a technical measure to facilitate search and rescue operations in the Strait. In this cooperative process, both sides could cooperate in installing EPIRBs and conducting exercises as a precursor to eventual military-to-military exchanges. In the long term, the use of video conference capabilities could be developed into crisis management and crisis prevention capabilities when the political opportunity arises.

- Vessel traffic management: When Taiwan and China fully develop the Three Links, maritime traffic in the Taiwan Strait will increase year by year. In order to improve and maximize the safety and efficiency of maritime traffic, they may develop a cooperative Vessel Traffic Services (VTS) system for the Taiwan Strait. It could be modeled after the systems successfully used across the Strait of Gibraltar between Spain and Morocco, and the Strait of Juan de Fuca between the United States and Canada. ${ }^{48}$ A typical VTS system might include separating the North-South SLOC traffic lanes and controlling the East-West, cross-Strait vessels to avoid collisions. This safety cooperation would require a control and communication center on each side of the strait, in nearly constant communication with each other.

\subsection{North Korea and South Korea}

The DPRK has little trade beyond some shipping with South Korea and China. Therefore, North Korea and South Korea may not be interested in anti-smuggling. Nevertheless, the two Koreas had serious gunfire exchanges in 1999 and 2002 near the Northern Limit Line in the West Sea (Yellow Sea). Under these circumstances, they have specific reasons to cooperate with each other to improve relations. From practical considerations, prevention of incursions on

48 For detailed information, see Abdellatif Abbassi, "Cooperative VTS in Morocco: Tangier Coastal VTS," and Dan MacDonald, "Development of a Cooperative VTS: The Strait of Juan de Fuca Example," in Maritime Safety Colloquium 2001 Proceedings, Aqaba, Jordan, August 5-9, 2001. 
fisheries, search and rescue, and maritime environmental protection are potential cooperation topics between the two Koreas.

- Prevention of incursions on fisheries: Serious maritime confrontations between North Korea and South Korea stand out as either acts of intentional policy, or at least poor management of individual fishing vessels. In addition, overlapping EEZs in the Yellow Sea present a difficult, long-term problem. Under these circumstances, tracking fishing vessels and delimitation of maritime boundaries are core approaches to managing maritime issues between the two Koreas. Real-time location and tracking systems, based on Global Positioning Satellite (GPS) transponders, can help track and control vessels of both sides to prevent fisheries incursions. In the disputed areas, GPS Boundary Mapper equipment on vessels and GPS Boundary Marking buoys in the waters could remind fishermen not to enter these areas. The South might offer to provide GPS systems to fishing vessels of the North as an incentive to accept this cooperation.

- Search and rescue: Search and rescue operations are another means of developing the preliminary trust that might lead to development of an INCSEA for the two Koreas. Communication and tracking capabilities are necessary for executing search and rescue operations. As a side benefit, a tracking system could also allow the North to control operators who provoke incidents by fishing too aggressively or who intrude into disputed waters. Hot lines, video conferencing, and tracking systems are all applicable to search and rescue operations that could defuse North-South Korea tensions and strengthen mutual trust and confidence.

- Maritime environmental protection: The NOWPAP of the UNEP includes Russia, China, Japan, and both Koreas. Two top issues in the action plan adapted in 1994 are pollution control and protection of fisheries. The NOWPAP oil spill cooperation provides a channel for North Korean participation in regional cooperation. While North Korea is said to have little or no capability to deal with oil spills, they are still vulnerable to the effects that a major event could have on their fishing areas. The first step toward involvement could be to assist North Korea to acquire and install some environment monitoring sensors. A next step might be to help with harbor pollution equipment or to include them as observers in a bilateral oil spill exercise between neighboring countries.

In the preceding discussions, some technical means were identified to help resolve maritime disputes and facilitate maritime cooperation in the Asia-Pacific region. Technical activities offer many politically acceptable opportunities to engage in cooperation. Except for sensitive maritime territorial disputes, other maritime issues can be approached as practical measures that can use technical means for resolution. Technologies offer flexible and practical options to support and achieve these objectives. 


\section{Conclusion}

The Asia-Pacific region is a maritime community. Avoiding maritime conflicts and protecting SLOCs is a common value for every nation in the region. Therefore, strengthening maritime cooperation and establishing regional technical cooperation would be beneficial to the interests of the Asia-Pacific countries. Although maritime cooperation would not resolve maritime territorial disputes, it could be applicable to anti-piracy, anti-smuggling, search and rescue, and pollution control issues. Modern technologies, such as commercial satellite imaging and tracking, Internet communications, and pollution monitoring systems, can help to strengthen maritime cooperation among nations and pave the way for progress on core issues.

In addition to diplomatic approaches, technical cooperation is a feasible approach to reduction of maritime disputes and protection of SLOCs. Through technical collaboration, we can reduce political and ideological obstacles among competing nations. Technical collaboration can enhance transparency and provide a neutral modality for mutually beneficial cooperation. Technology can offer the following advantages in applications to maritime cooperation:

- reducing distrust and suspicion among parties by strengthening transparency regimes;

- establishing a maritime code of conduct;

- having issue linkage to enable the approach to more sensitive issues;

- reducing conflict and war risk due to miscalculation or misjudgments;

- having deterrent effects by increasing the cost and risk for breaking the status quo; and

- monitoring to preserve the current situation as a sound foundation for peaceful resolution.

Many maritime affairs have strong technical aspects. Therefore, maritime cooperation should involve technical issues as steps toward resolving maritime disputes. Under these circumstances, Asia-Pacific countries can convene appropriate technical workshop groups to discuss maritime issues of the Asia-Pacific region. In addition, bilateral technical assistance also can mitigate the tense situations across the Taiwan Strait and on the Korean Peninsula. A technical collaboration approach can facilitate cooperation on functional issues to pursue resolution of political issues in a step-by-step manner. 
Cooperative Measures to Mitigate Asia-Pacific Maritime Conflicts

This page intentionally left blank. 


\section{Appendix-Principal Territorial Disputes of East Asia}

\section{Northern Territories}

Etorofu, Kunashiri, Shikotan, and Habomai Islands, known as the Northern Territories, reach north to Kamchatka from the eastern end of Hokkaido. ${ }^{49}$ The Northern Territories have been a source of rivalry between Japan and Russia since the beginning of the $17^{\text {th }}$ century. ${ }^{50}$ On February 7, 1855, Japan and Russia signed the Treaty of Shimoda, which stipulated that the boundary "between Russia and Japan will pass between the islands of Iturup and Uruppu" with those islands to the north belonging to Russia and those to the south to Japan. ${ }^{51}$ In May 1874, both sides signed the Treaty of Saint Petersburg, ceding to the Meiji Emperor those Kuril Islands which Russia held in exchange for Japan's withdrawal from Sakhalin. ${ }^{52}$

In August 1945, the Soviet Union declared war against Japan and then occupied the four islands claimed by Tokyo. Since the end of World War II, the Kuril Islands dispute has been a stumbling block to Japanese-Russian relations. ${ }^{53}$ In October 1956, Tokyo and Moscow signed a joint declaration that ended the state of war between them and the Soviet Union agreed that it would transfer Habomai and Shikotan to Japan on the conclusion of a peace treaty. ${ }^{54}$ However, when the United States and Japan renegotiated their Mutual Security Treaty in 1960, the Soviet Union informed Japan that it would return Habomai and Shikotan to Japan only after termination of all foreign base rights, the departure of troops from Japan, and after the two states had signed a peace treaty. ${ }^{55}$ Before the Soviet Union collapsed, Mikhail S. Gorbachev suggested the return of Habomai and Shikotan to Japan, because these two islands were of little military value to the Soviet Union. Japan insisted that all of the Northern Territories be returned and refused the Soviet suggestion. ${ }^{56}$ The Northern Territories dispute between Japan and the Soviet Union involved political, strategic, and ideological aspects of the Cold War era, which were connected to the larger West-East confrontation.

When the Cold War ended, Japanese and Russian bilateral relations gradually improved. In October 1993, Russian President Boris Yeltsin visited Japan, and he and then-Prime Minister Morihiro Hosokawa signed the Tokyo Declaration. They agreed that the guidelines of negotia-

49 Captain James F. Giblin, Jr., "National Strategies and Japan's Northern Territories," Naval War College Review, Winter 1987, p. 53.

50 Ibid., p. 55.

51 George A. Lensen, The Russian Push Toward Japan: Russo-Japanese Relations 1697-1895 (Princeton, N.J.: Princeton University Press, 1959), p. 475.

52 Hugh Borton, Japan's Modern Century: From Perry to 1970, $2^{\text {nd }}$ ed. (New York: Russell and Russell, 1981), p. 436.

53

“Ilands May Bridge Russia-Japan Gap," http://www.stratfor.com/home/giu/archive/03200.

54 Captain James F. Giblin, Jr., "National Strategies and Japan’s Northern Territories," p. 59.

55

56 Ibid.

6 "Strategic Considerations: Northern Territories Disputes Continued," United Daily, November 16, 1996, p. 10. For the Soviet Union, Japan, and the United States, the waters surrounding the Northern Territories are an important strategic area. Petropavlovsk is the most important naval base in the Soviet Pacific region, located in the south of Kamchatka Peninsula. Its supply heavily depends upon Vladivostok. This supply line passes through Habomai Strait, which is northwest of Habomai Island. In addition, the Northern Territories separate the Sea of Okhotsk from the Pacific Ocean. 
tions toward resolution would be (a) based on historical and legal facts; (b) based on documents compiled with the agreement of the two countries; and (c) based on the principles of law and justice. $^{57}$ In July 1997, Japanese Prime Minister Obuchi declared that Japan and Russia would cooperate to exploit the Far East region. Obuchi advocated that both sides set aside the Northern Territories dispute - an important turning point for Japan towards Russia. ${ }^{58}$ In November 1997 , Obuchi made an official visit to Russia as the first Japanese Prime Minister to do so in 25 years. A summit meeting with President Yeltsin resulted in both leaders signing an agreement to resolve the dispute by the year 2000 based on the Tokyo Declaration. ${ }^{59}$

In September 2000, when Russian President Vladimir Putin visited Japan, people looked forward to a thorough resolution of the issue that had been pending for more than a half century. ${ }^{60}$ In March 2001, Japanese Prime Minister Yoshiro Mori visited Irkutsk. Mori and Putin confirmed the Japan-Soviet Joint Declaration of 1956 as the basic legal document to set a starting point for the negotiation process. In addition, they confirmed that, based on the 1993 Tokyo Declaration, a peace treaty should be concluded by resolving the issue of the Four Islands (The Irkutsk Statement). ${ }^{61}$ Currently, different perceptions persist between both sides: Japan asks Russia to recognize Japanese sovereignty over the Northern Territories and requests that Russia return the Four Islands to Japan as soon as possible. On the other hand, Russia is focused on joint exploitation of the Four Islands and links this issue to Siberian economic assistance by Japan. Therefore, the Northern Territories dispute between Japan and Russia is not only a maritime conflict, but also involves important political-economic issues. It does not appear that sovereignty over the Northern Territories will be resolved in the short term.

\section{Diaoyutai/Senkaku Islands}

The Diaoyutai/Senkaku Islands are comprised of five islands and three rocks located about $120 \mathrm{~nm}$ northeast of Taiwan, $200 \mathrm{~nm}$ east of mainland China, and $190 \mathrm{~nm}$ southwest of Okinawa. $^{62}$ The uninhabited islands cover only about 6.3 square kilometers. In 1941, Japan occupied Taiwan, and the then-Taipei State and Okinawa County disputed which should have jurisdiction over the Senkaku Islands. In 1944, the Tokyo Court awarded jurisdiction over the Senkaku Islands to the Taipei State. In 1945, the Republic of China recovered Taiwan and claimed that the Senkaku Islands were still a part of the Taiwan State and hence, of China. ${ }^{63}$

\footnotetext{
57 See http://www.mofa.go.jp/region/europe/russia/territory/overview.html.

58 "Obuchi Gives a Grand Gift to Russia: Japan and Russia Mutually Benefit," China Times, November 3, 1997, p. 10.

59 "Japan's Northern Territories," http://www.mofa.go.jp/region/europe/russia/territory/index.html.

60 Doug Struck, "Russia, Japan Oceans Apart on Islands," Washington Post, September 5, 2000, p. 16.

61 "Overview of the Issue of the Northern Territories," http://www.mofa.go.jp/region/europe/territory/overriew. Html.

62 The five islands are Huangwei Yu/Kuba-shima or Kobi Sho, Chiwei Yu/Taisho-jima or Akao-sho, Diaoyutai Dao/Uotshuri-shima, Beixiao Dao/Kita Kojima, and Nanxiao Dao/Minami Kojima or Minami-ko-shima. The three rocks are Dabeixiao Dao/Okino Kitaiwa, Dananxiao Dao/Okino Minamiiwa, and Feilai Dao/Tobise. See Rear Admiral William L. Schachte, Jr., "The United States' Role in the Diaoyutai/Senkaku Islands Dispute," quoted in International Law Conference on the Dispute over the Diaoyutai/Senkaku Islands between Taiwan and Japan (I-Lan: I-Lan County Government, 1997), p. 2.

63 Zhou Yu-shan, "Diaoyutai Incident and People's Republic of China," Studies on Chinese Communism Monthly, Vol. 30, No. 10 (October 1996), p. 20.
} 
In the 1970s, the UN Economic Commission for Asia and the Far East reported with high probability that the continental shelf between Taiwan and Japan may be one of the richest oil reservoirs in the world. ${ }^{64}$ They estimated that the deposit may be equal to that of the Persian Gulf. Later, when the United States returned Okinawa to Japan, Japan adopted more active measures and claimed sovereignty over the Senkaku Islands. Thus, the Senkaku Islands sovereignty has become a maritime dispute among China, Taiwan, and Japan. This maritime dispute is still pending. ${ }^{65}$

China, Taiwan, and Japan adopt different approaches to deal with the Diaoyutai/Senkaku Islands issue. For example, Japan's claim is based on the discovery that the islands were terra nullius (unclaimed). On the other hand, Taiwan declared that Chinese had discovered the "Diaoyutai Islands" and thereby were entitled to sovereignty. However, Taiwan did not follow international practice and declare the sovereignty by national pronouncement or official activities. In the disagreement between Taiwan and Japan, international political reality favored Japan, and Taiwan did not put forth much effort on this issue. ${ }^{66}$ In addition to Japan and Taiwan, China is also involved in the Diaoyutai Islands dispute. In the 1970s and 1980s, China was preoccupied with internal issues and had insufficient naval capabilities to adopt a strong posture dealing with the political, diplomatic, and military aspects of the issue. Under these circumstances, China considered the Diaoyutai Islands dispute to be a sovereignty issue between Japan and Taiwan.

With economic growth into the 1990 s, China continued to introduce advanced weapon systems and increased its participation in international affairs. Gradually, China accumulated tremendous military strength and diplomatic capital that could enable it to deal with the Diaoyutai Islands dispute. From 1996 to the present, China and Japan have had several confrontations over the Islands. Notably, China has not adopted strong measures against Japan, but has only used a diplomatic approach to declaring sovereignty. It can be argued that China was concerned that if relations deteriorated, Japan might terminate economic aid to China. Therefore, China adopted a low-key and ambiguous attitude towards the issue. ${ }^{67}$

${ }^{64}$ Kenneth Y. Choy, "Overview of Taiwan's Legal and Jurisdictional Considerations in the Diaoyutai/Senkaku Dispute," quoted in International Law Conference on the Dispute over the Diaoyutai/Senkaku Islands Between Taiwan and Japan (I-Lan: I-Lan County Government, 1997), p. 1.

Chen Yeong-kang and Chai Wen-chung, "Modernization of the PLAN: Implications for Asia-Pacific Security," Mainland China Studies, Vol. 42, No. 7 (July 1999), p. 11; Chen Yeong-kang and Chai Wen-chung, "A Study of Diaoyutai Islands Sovereignty," R.O.C.N. Proceedings, Vol. 31, No. 1 (January 1997), p. 23.

66 In addition to government declarations, civilian sectors launched "Protection of the Diaoyutai Islands" movements three times. The first occurred in February 1970, when Taiwanese students at the University of Chicago established the "Protect Diaoyutai Islands Action Committee." They demonstrated and raised money to support sovereignty over the Diaoyutai Islands. Several years later, "Protect Diaoyutai Action" was conducted domestically and abroad. In the second "Protect Diaoyutai Islands" movement in 1990, Wu Dun-yi, Mayor of Kaohsiung, declared that the Taiwan Regional Athletic Meet would transfer to the Islands to remove a navigation beacon placed by the Japanese Youth Association. At midnight, October 21, the Taiwan youths traveled by fishing boats from I-Lan County to the Diaoyutai Islands. On the afternoon of the same day, the fishing boats were intercepted and turned back by the Japanese Maritime Security Agency. The third occasion occurred in 1996, when the Japan Youth Association again erected a navigation beacon. These actions irritated ethnic Chinese around the world. Later, China quelled the "Protection of the Diaoyutai Islands" movement and this activity has concluded. See Zhou Yu-shan, "Diaoyutai Incident and People's Republic of China," pp. 20-21.

Chen Yeong-kang and Chai Wen-chung, "Modernization of the PLAN: Implications for Asian-Pacific Security," p. 11. 
For China, the Diaoyutai Islands may be an important access point for the People's Liberation Army Navy (PLAN) from the East China Sea to the Pacific Ocean.

Diaoyutai sovereignty affects huge potential EEZ claims for China and Japan. Okinawa is clearly Japanese territory, whether by application of UNCLOS Article 121 "Regime of Islands" or by practicing straight-line principles; however, the Japanese use of Diaoyutai and Yonagunijima as their base point for declaring the 200-nm EEZ is considered by some a serious infringement of Chinese interests. ${ }^{68}$ Japanese sovereignty over the Diaoyutai/Senkaku Islands could invoke the principle of "equidistance" to share several hundred thousand square kilometers of continental shelf with China. ${ }^{69}$ China may dislike this development. Currently, China needs Japanese financial aid (i.e., low-interest loans) to support economic development, ${ }^{70}$ so China refrains from criticizing Japan and increasing tensions. Nevertheless, with Chinese naval capabilities expanding and the "Concept of Sea as National Territory" rising, China attaches increasing significance to the Islands. The best example of this is the appearance of Chinese intelligence ships in waters surrounding the islands. It is possible that China and Japan may clash over the sovereignty issue.

\section{South China Sea}

The South China Sea is a semi-enclosed sea that extends from approximately 3 degrees south latitude to 23 degrees north latitude and is surrounded by China, Vietnam, Malaysia, Singapore, Brunei, the Philippines, and Taiwan. The width of the South China Sea, from Vietnam across the Spratlys to Balabac Island in the Philippines, is approximately 600 miles. Its surface area covers $1,148,500$ square miles ${ }^{71}$ and includes four archipelagos, the Paracel Islands, Pratas Islands, Macclesfield Bank, and Spratly Islands. The presumed existence of large oil and gas deposits in these waters and the strategic importance of shipping lines between the Pacific Ocean and the Indian Ocean have increased the risk of confrontations over disputed areas of the South China Sea. ${ }^{72}$ Like the Korean Peninsula and Taiwan Strait, the South China Sea is one of the three contentious areas in the Asia-Pacific region. ${ }^{73}$

In the South China Sea, the Spratly Islands are the most disputed area. A 1995 study by Russia's Research Institute of Geology of Foreign Countries estimated that the equivalent of 6

68 See United Nations Convention on the Law of the Sea Article 7, "Straight baselines"; Article 47, "Archipelagic baselines"; Article 48, "Measurement of the breadth of the territorial sea, the contiguous zone, the exclusion economic zone and the continental shelf;" and Article 49, "Legal status of archipelagic waters, of their air space over archipelagic waters and of their bed and subsoil," United Nations, The Law of the Sea: United Nations Convention on the Law of the Sea with Index and Final Act of the Third United Nations Conference on the Law of the Sea (New York: United Nations Publication, 1983), pp. 4, 15-6.

69 Lieutenant Commander Duk-Ki Kim, "Cooperative Maritime Security in Northeast Asia." See http://www.nwc. navy.mil/press/Review/1999/winter/art3-w99.htm.

http://www.nwc.navy.mil/press/Review/2001/Autumn/art4-aul.htm.

71 "Competing Claims of Vietnam and China in the Vanguard Bank and Blue Dragon Areas of the South China Sea: Part I," http://www.cov.com/publications/CLAGETT1.asp.

72 Richard E. Hull, "The South China Sea: Future Source of Prosperity or Conflict in South East Asia?" Strategic Forum, No. 60, February 1996.

73 Ding Zong-yu, "National Territories Disputes Between China and Nations Neighboring the South China Sea," Studies in Communism, April 1995, p. 39. 
billion barrels of oil might be located in the Spratly Islands area, of which 70 percent would be natural gas. On the other hand, some Chinese specialists have asserted that the South China Sea could contain as much as 130 billion barrels of oil and natural gas. ${ }^{74}$ Inevitably, the neighboring nations of the South China Sea will contest control of such enormous resources. Currently, the disputed areas are claimed all or in part by China, Taiwan, Vietnam, the Philippines, Malaysia, Brunei, and Indonesia. Conflicts have occurred between China and Vietnam, China and the Philippines, the Philippines and Malaysia, Vietnam and the Philippines, the Philippines and China. ${ }^{75}$

On February 25, 1992, the $7^{\text {th }}$ National People's Congress promulgated "The Law on the Territorial Sea and the Contiguous Zone." Article 2 identified the Spratly Islands and several other mid-ocean land features as Chinese territory. China unilaterally declared the Spratly Islands as its territory; in response, neighboring nations strongly protested China's claim. ${ }^{76}$ China based its claim on international law as the "historic occupation and/or use." Other claimants refused to recognize China's declaration, because China did not effectively occupy these islands. $^{77}$

China and ASEAN countries approach the issue from different viewpoints. According to Chinese scholars' points of view, the major cause of the dispute is that the ASEAN countries use contemporary international law to challenge China's historic rights. China prefers to use bilateral negotiations to resolve the ownership, and not use multilateral or international approaches. ${ }^{78}$ China's power projection capabilities (naval and long-range air forces) are probably not yet up to the task of combat operation such a long distance from the Chinese mainland. Under these circumstances, China depends upon appeals for peaceful bilateral negotiation to maintain their new status quo.

In August 1990, People's Republic of China (PRC) Premier Li Peng visited Singapore and publicly stated that China will shelve the sovereignty dispute in favor of joint development

74 See United States Institute of Peace Special Report, "The South China Sea Dispute: Prospects for Preventive Diplomacy," http://www.usip.org/oc/sr/snyder/South_China_Sea1.html.

75 For conflict descriptions, see Lu Ru-chun et al., Hai Jun Shi (The History of People's Liberation Army Navy) (Beijing: PLA Press, 1989), p. 335; http://www.eia.doe.gov/emeu/cabs/schinatab.html\#TAB2; Trevor Hollingsbee, "China Moves in on Mischief Reef," Jane's Intelligence Review, January 1999, p. 5; Barbara Opall, "ASEAN Counters China Territorial Claims," Defense News, July 29 - August 4, 1996, pp. 4, 56; "Philippines Protests Attack by Vietnamese in Spratlys," Taiwan News, October 29, 1995, p. 5; "China Fishing Boat Collided with the Philippine Naval Ship on the Huangyan Dao in the South China Sea," United Daily, May 25, 1999, p. 13; "Philippine and Malaysia Fighting Aircraft Confrontation in the South China Sea Air," United Daily, November 3, 1999, p. 11; Run Bei, "What Huangyan Dao Incident Present?," Jian Chuan Zhi Shi (Warships and Merchant Ships) (Beijing), No. 214 (July 1997), p. 10.

${ }^{76}$ Eric Hyer, "The South China Sea Dispute: Implications of China's Earlier Territorial Settlements," Pacific Affairs, Spring 1995, p. 41; B. A. Hamzah, "China's Strategy," Far Eastern Economic Review, August 13, 1992, p. 22.

77 Geoffrey Till, “China, Its Navy and the South China Sea,” RUSI Journal, April 1996, p. 48.

78 Xiao Quan-zheng and Chen Zhi-ping, "The Introduction of the South China Sea Seminar," National Policy Dynamic Analysis, No. 96 (October 1994), p. 2. 
of the South China Sea. ${ }^{79}$ In August 1995 at the ASEAN Regional Forum (ARF) held in Brunei, PRC Foreign Minister Qian Qichen promised that the PRC would pursue a solution consistent with the UNCLOS, and further declared that the PRC claim did not contradict the right of safe passage through international waterways in the South China Sea. ${ }^{80}$ In December 1997, PRC President Jiang Zemin and the heads of ASEAN countries signed a Joint Declaration to “...renounce use of force or threat of use of force. Claimants should be in accordance with international law, including 1982 UNCLOS, to resolve the South China Sea disputes through peaceful consultation and negotiation. ${ }^{, 81}$ Nevertheless, China has refused to adopt a multilateral approach to resolve the dispute. By pursuing the dual tactics of "sovereignty belongs to me" and "shelve the sovereignty dispute in favor of joint development," China seeks to maintain freedom of operation in the South China Sea issue.

Many disputes concern the South China Sea. In August 1999, the Philippines drafted the South China Sea Code of Conduct for consideration at the ASEAN and China informal summit meeting in November of that year. Because China rejected the draft Code of Conduct, this code has not been transferred into concrete policy. ${ }^{82}$ In addition, the United States and Japan have been concerned with the situation in the South China Sea, particularly focusing on freedom of navigation. ${ }^{83}$ With PLAN power projection capability rising and in the face of competition to exploit oceanic resources, serious confrontations may appear in the South China Sea. A major conflict between the ASEAN nations and China could instigate intervention by outside powers to maintain freedom of navigation. As with the Balkan situation before World War I, the South China Sea may be a flashpoint in the Asia-Pacific region. ${ }^{84}$

79 Gerald Segal, "East Asia and the 'Constrainment' of China," International Security, Vol. 20, No. 4 (Spring 1996), p. 118; Abdul Razak Abdullah Baginda, "Strategic Scenarios in the South China Sea," National Policy Dynamic Analysis, No. 96 (October 1994), pp. 3-4.

80 http://www.usip.org/oc/sr/snyder/South_China_Seal.html

81 "PRC and ASEAN Heads Joint Declaration: Bilateral Cooperation toward the Twenty-First Century," Jiefangjun Bao (PLA Daily), December 17, 1997, p. 5.

82 Song Yann-huei, "ASEAN and PRC Negotiation with the South China Sea Code of Conduct Impact to the Taiwan Security," Collection of Taiwan's National Security and the South China Sea Dispute Conference (Taipei: Division of Strategy and International Studies, Taiwan Research Institute, 2000), pp. 2.4-2.5.

83 Joseph W. Prueher, former Commander in Chief of the U.S. Pacific Command, stated: "If any claimants of the South China Sea sovereignty disputes endangered the freedom of navigation, the U.S. would adopt appropriate response... but we don't interpret what is, we use measures." When Dennis C. Blair assumed that office he also stated: "Claimants should negotiate to solve differences among them, not use intimidation measures to achieve objectives." See Song Yann-huei, "The Influence of Ratification 1982 UNCLOS by the South China Sea Claimants," National Policy Dynamic Analysis, No. 171 (August 1997), pp. 8-9; "U.S. Urge to Guarantee Freedom of Navigation in the South China Sea," United Daily, June 19, 1997, p. 10; "Blair Appeals for Peaceful Resolution for the South China Sea Disputes," China Times, May 23, 1999, p. 14.

Jing-dong Yuan, "China's Defense Modernization: Implications for Asia-Pacific Security," Contemporary Southeast Asia, Vol. 17, No. 1 (June 1995), p. 75; Eric Hyer, "The South China Sea Dispute: Implications of China's Earlier Territorial Settlement," p. 41; James L. George, "China: Paper or Potential Tiger?," Naval Forces, February 1996, p. 96. 


\section{About the Author}

Commander Chai, Wen-Chung is a staff member of the Strategic Planning Department of the Ministry of National Defense in Taiwan. He received his MA in International Affairs and Strategic Studies at the University of Tamkang and a BA from the Chinese Naval Academy. Cdr. Chai has served on many naval vessels and in several shore positions for the Taiwan Navy. $\mathrm{He}$ is the author and co-author of numerous publications, including Taiwan Survival and Seapower Development, PRC Military Capabilities Assessment 2010, Revolution in Military Affairs, and Asia-Pacific Security: Theory and Practice. He is the author of several articles related to naval strategy, naval policy, military strategy, and military balance across the Taiwan Strait. 


\section{Distribution}

350 MS 1373 CMC Library, 5341

1 MS 9018 Central Tech Files, 8945-1

2 MS 0899 Technical Library, 9616

1 MS 0612 Review \& Approval Desk, 96121 